\title{
HUBUNGAN ANTARA PENGETAHUAN TENTANG PROSES PERSALINAN DENGAN TINGKAT KECEMASAN DALAM MENGHADAPI PERSALINAN PADA IBU HAMIL DI WILAYAH SUKOHARJO
}

\author{
Sri Aminingsih ${ }^{1}$, Agatha Grace Anggriani ${ }^{2}$
}

\begin{abstract}
Know can be defined as considering a items which have been studied previously. This matter can be interpreted that pregnant mother which have owned previous experience or knowledge will affect at behavior, in this case is anxiety which can happened at pregnant mother when previously do not obtain knowledge about labour process. Pursuant to brief interview at some pregnant mother say that in this time experience of anxiety because will face labour. Some pregnant mother tell not yet had experience bear and do not know how process bear which in fact when can bear normally. The purpose of this study was to know knowledge relation about labour process with anxiety level in face of labour.

The Subjects who involed as population in this research were 52 womans who pregnant in trimester II and trimester III. This research represent analytic research with desain research of correlation. While used by plan is sectional cross.

From result of Pearson Corelation SPSS version program test 18.0 with $=5 \%(0.05)$ obtained $p$ equal to 0,001 so that assess $p<0.05$, with result of correlation $-0,928$. It can be conclusion that is negative correlation between knowledge with anxiety level in face of copy process pregnant mother in Sukoharjo region.
\end{abstract}

Keywords: Knowledge and anxiety level.

\section{PENDAHULUAN}

Mengutip data hasil Survei Demografi Kesehatan Indonesia (SDKI) tahun 2012, Angka Kematian Ibu (AKI) di Indonesia mencapai 359 per 100.000 kelahiran hidup dan Angka Kematian Bayi (AKB) mencapai 32 per 1000 kelahiran hidup. Melengkapi hal tersebut, data laporan dari daerah yang diterima Kementerian Kesehatan RI menunjukkan bahwa jumlah ibu yang meninggal karena kehamilan dan persalinan tahun 2013 adalah sebanyak 5019 orang. Sedangkan jumlah bayi yang meninggal di Indonesia berdasarkan estimasi SDKI 2012 mencapai 160.681 anak. Kematian ibu terjadi pada perempuan yang terlalu muda untuk hamil, ada juga yang terlalu tua untuk hamil, jarak kehamilan yang terlalu berdekatan, serta kehamilan yang terlalu sering. Selain itu, terdapat beberapa kondisi lainnya seperti: Anemia pada penduduk usia 15-24 tahun masih tinggi yaitu sebesar 18,4\% (Riskesdas, 2013); Perkawinan usia dini masih tinggi yaitu sebesar 46,7\% (Riskesdas, 2010); Angka kelahiran pada usia remaja juga masih tinggi yaitu sebesar 48 per 1.000 perempuan usia 15-19 tahun (SDKI, 2012); dan kebutuhan pelayanan KB yang tidak terpenuhi atau unmet need masih relatif tinggi, yaitu sebesar 8,5\%.(Departemen Kesehatan Republik Indonesia, 2014)

Banyak ibu yang merasa cemas dan khawatir saat mereka hamil, hal ini sering terjadi terutama pada ibu yang baru pertama kali melahirkan. Kecemasan adalah suatu perasaan tidak santai yang samar-samar karena ketidaknyamanan atau rasa takut yang disertai suatu respon (sumber sering kali tidak spesifik atau tidak diketahui oleh individu) suatu perasaan takut akan terjadi 
sesuatu yang disebabkan oleh antisipasi bahaya. Hal ini merupakan sinyal yang menyadarkan bahwa peringatan tentang bahaya yang akan datang dan memperkuat individu mengambil tindakan menghadapi ancaman. (Fitria , Sriati, dan Hernawaty, 2013)

Kehamilan merupakan proses psikologis yang memberikan perubahan pada ibu maupun lingkungannya. Dengan adanya kehamilan maka seluruh sistem genetalia wanita mengalami perubahan yang mendasar untuk mendukung perkembangan dan pertumbuhan janin dalam rahim selama proses kehamilan berlangsung. (Hutahaean, 2013)

Kehamilan merupakan suatu peristiwa yang penting dalam kehidupan seorang wanita dan keluarga pada umumnya, walaupun perubahan besar yang akan terjadi sangat mempengaruhi semua orang terutama wanita. Kehamilan juga dapat diartikan saat - saat krisis, saat terjadi gangguan dan perubahan identitas serta peran bagi setiap anggota keluarga. Setiap individu berespon terhadap krisis tersebut dengan cara yang berbeda sesuai dengan sifat kejadian yang ada dalam kehidupannya. Definisi krisis ini merupakan suatu ketidakseimbangan psikologis yang mungkin disebabkan oleh situasi atau tahap perkembangan si ibu. Pada awalnya bagi sebagian ibu hamil untuk pertama kalinya mengalami periode syok, menyangkal, kebingungan serta tidak terima atas apa yang terjadi persepsi setiap wanita saat dia mengetahui akan kehamilan tersebut, yang ada dalam pikirannya bahwa kehamilan merupakan suatu penyakit, kejelekan pada dirinya atau mungkin mereka memandang bahwa kehamilan adalah suatu periode kreatifitas dan pemenuhan pengabdian pada keluarga oleh karena itu, berbagai dukungan dan bantuan sangat penting dibutuhkan bagi seorang ibu untuk mendukung selama kehamilannya. (Hutahaean, 2013)

Banyak penelitian telah menggali hubungan perasaan ibu terhadap hasil kehamilannya. Sebagai contoh, apa pengaruh keadaan mood yang negatif, seperti depresi pada persalinan, kelahiran, dan hasil akhir neonatal atau, apa hubungan antara hasil akhir kehamilan dengan konflik emosi, cemas, stress atau harga diri rendah. Penelitian terbaru juga telah berfokus pada harapan ibu mengenai kehamilan dan kelahiran dan hubungan perasaan ibu tentang pencapaian, kepuasan, dan kesejahteraan emosi. (Walsh, 2008) Umumnya dapat diterima bahwa seorang ibu mempunyai perasaan yang ambivalen tentang menjadi hamil pada awal kehamilannya. Pada kenyataannya terdapat sedikit informasi penelitian tentang bagaimana para ibu merasakan diri mereka dan perasaan mereka sepanjang kehamilan. Dengan mendorong ibu menceritakan tentang perasaannya dapat memfasilitasi perawatan klinis, dan bertanya tentang perasaan orang lain dalam jaringan sosialnya juga dapat berguna. Perasaan sejahtera atau percaya diri, serta perasaan stress dan cemas berhubungan dengan proses biofisik dan psikologis yang dialami oleh ibu hamil. Perubahan mood yang paling sering selama kehamilan telah dilaporkan, yaitu menjadi cemas dan depresi. Para peneliti umumnya melaporkan bahwa perasaan ini berfluktuasi sepanjang masa kehamilan. (Walsh, 2008)

Banyak ibu merasa khawatir saat mereka hamil, terutama terhadap kesehatan bayi dan terhadap persalinan. Kekhawatiran ibu tentang masalah lain dalam hidup juga dapat menjadi lebih besar saat 
dia hamil. Kekhawatiran tersebut normal dan tidak menandakan bahwa sesuatu yang buruk akan terjadi. (Klein, Miller, dan Thomson, 2012)

Tahu diartikan sebagai mengingat suatu materi yang telah dipelajari sebelumnya. Termasuk ke dalam pengetahuan tingkat ini adalah mengingat kembali (recall) terhadap suatu yang spesifik dan seluruh bahan yang dipelajari atau oleh rangsangan yang diterima. (Wawan dan Dewi, 2011) Hal ini bisa diartikan bahwa ibu hamil yang sudah memiliki pengetahuan atau pengalaman sebelumnya akan berdampak pada perilaku, dalam hal ini adalah kecemasan yang bisa terjadi pada ibu hamil bila sebelumnya tidak memperoleh pengetahuan tentang proses persalinan.

Berdasarkan hasil studi pendahuluan yang dilakukan oleh peneliti di poliklinik desa wilayah Sukoharjo terdapat sekitar 15 ibu hamil yang memeriksakan kehamilannya secara rutin setiap bulan, hasil wawancara singkat pada beberapa ibu hamil mengatakan bahwa saat ini mengalami kecemasan karena akan menghadapi persalinan. Beberapa ibu hamil mengatakan belum mempunyai pengalaman melahirkan dan tidak tahu bagaimana proses melahirkan yang sebenarnya bila bisa melahirkan dengan normal.

\section{TUJUAN PENELITIAN}

1. Tujuan Umum

Untuk mengetahui hubungan pengetahuan tentang proses persalinan dengan tingkat kecemasan dalam menghadapai persalinan pada lbu Hamil di wilayah Sukoharjo.

2. Tujuan Khusus
a. Mengetahui
gambaran pengetahuan tentang proses persalinan pada ibu hamil di Wilayah Sukoharjo.

b. Mengetahui gambaran tentang tingkat kecemasan dalam menghadapi persalinan pada ibu hamil di Wilayah Sukoharjo.

\section{DESAIN PENELITIAN}

Penelitian ini merupakan penelitian analitik dengan desain penelitian korelasi. Sedangkan rancangan yang digunakan adalah cross sectional untuk mencari hubungan antara pengetahuan tentang proses persalinan dengan tingkat kecemasan dalam menghadapi persalinan pada ibu hamil di wilayah Sukoharjo.

\section{POPULASI, SAMPEL, DAN TEHNIK SAMPLING}

Populasi pada penelitian ini adalah semua ibu hamil trimester II dan III yang sedang memeriksakan kehamilannya di wilayah Sukoharjo yaitu sebanyak 52 ibu hamil. Dalam penelitian ini, peneliti menggunakan teknik accidental sampling, dimana cara pengambilan sampel ini dilakukan dengan memilih sampel yang kebetulan ada pada saat penelitian dalam hal ini dibatasi pada bulan Mei sampai Juli 2016.

\section{HASIL PENELITIAN}

1. Karakteristik Responden

Berdasarkan penelitian yang telah dilakukan mulai bulan Mei 2016 didapatkan karakteristik responden sebagai berikut : Tabel 1.

Distribusi Frekuensi Karakteristik Responden Berdasarkan Umur

\begin{tabular}{ccc}
\hline $\begin{array}{c}\text { Kelompok } \\
\text { Umur lbu (Th) }\end{array}$ & $\mathrm{f}$ & $\%$ \\
\hline $20-25$ & 23 & 44,23 \\
$26-30$ & 12 & 23,07 \\
$31-35$ & 17 & 32,70 \\
\hline Total & 52 & 100 \\
\hline
\end{tabular}

Dari tabel 1. di atas diperoleh informasi bahwa responden dengan prosentasi paling tinggi terdapat pada kelompok umur 
20-25 tahun berjumlah 23 responden $(44,23 \%)$. Tabel 2.

Distribusi Frekuensi Karakteristik Responden Berdasarkan Riwayat Kehamilan

\begin{tabular}{ccc}
\hline $\begin{array}{c}\text { Riwayat } \\
\text { Kehamilan }\end{array}$ & $\mathrm{f}$ & $\%$ \\
\hline 1 & 25 & 48,08 \\
2 & 21 & 40,38 \\
$\geq 3$ & 6 & 11,54 \\
\hline Total & 52 & 100 \\
\hline
\end{tabular}

Dari tabel 2. di atas diperoleh informasi riwayat kehamilan dengan prosentasi paling tinggi terdapat pada responden yang mengalami kehamilan pertama kali berjumlah 25 responden $(48,08 \%)$.

2. Hasil Penelitian

Tabel 3.

Distribusi Frekuensi Pengetahuan

\begin{tabular}{ccc}
\hline Pengetahuan & $\mathrm{f}$ & $\%$ \\
\hline Rendah & 14 & 26,92 \\
Sedang & 17 & 32,70 \\
Tinggi & 21 & 40,38 \\
\hline Total & 52 & 100 \\
\hline Dari tabel & 3. di atas dapat \\
dicermati bahwa prosentasi & baling tinggi pada tingkat \\
pengetahuan dengan kategori \\
tinggi berjumlah 21 responden \\
$(40,38 \%)$.
\end{tabular}

Tabel 4.

Distribusi Frekuensi Tingkat Kecemasan Dalam Menghadapi Persalinan

\begin{tabular}{lcc}
\hline Kecemasan & $\mathrm{f}$ & $\%$ \\
\hline Tidak cemas & 11 & 21,15 \\
Ringan & 10 & 19,23 \\
Sedang & 17 & 32,70 \\
Berat & 14 & 26,92 \\
\hline Total & 52 & 100 \\
\hline Dari tabel 4. & di atas dapat \\
dicermati bahwa prosentasi & baling tinggi terdapat pada \\
tingkat kecemasan menghadapi \\
proses persalinan dengan \\
kategori sedang berjumlah 17 \\
responden (32,70\%).
\end{tabular}

Tabel 5.

Hasil uji Pearson Corelation

\begin{tabular}{|c|c|c|c|}
\hline & & $\begin{array}{l}\text { Penge- } \\
\text { tahuan }\end{array}$ & $\begin{array}{l}\text { Kece- } \\
\text { masan }\end{array}$ \\
\hline \multirow{2}{*}{$\begin{array}{l}\text { Penge- } \\
\text { tahuan }\end{array}$} & $\begin{array}{l}\text { Pearson } \\
\text { Corelation }\end{array}$ & 1 &,$- 928^{\star *}$ \\
\hline & $\begin{array}{l}\text { Sig.(2- tailed) } \\
N\end{array}$ & 52 & $\begin{array}{c}, 000 \\
52\end{array}$ \\
\hline \multirow[b]{2}{*}{ Kecemasan } & $\begin{array}{l}\text { Pearson } \\
\text { Corelation }\end{array}$ &,$- 928^{* *}$ & 1 \\
\hline & Sig.(2- tailed) & $\begin{array}{c}, 000 \\
52\end{array}$ & 52 \\
\hline
\end{tabular}

Dari tabel 5. di atas berdasarkan hasil uji Pearson Corelation program SPSS versi 18.0 dengan $\alpha=5 \%$ (0.05) diperoleh $p<0,001$ sehingga nilai $p<0.05$, yang berarti $\mathrm{H}_{\mathrm{o}}$ ditolak dan $\mathrm{H}_{\mathrm{a}}$ diterima, sehingga ada korelasi negatif antara pengetahuan dengan tingkat kecemasan dalam menghadapi proses persalinan pada ibu hamil di wilayah Sukoharjo.

\section{PEMBAHASAN}

1. Tingkat Pengetahuan

Dari tabel 3. dapat dicermati bahwa prosentasi pada tingkat pengetahuan dengan kategori rendah berjumlah 14 responden (26,92\%), sedang berjumlah 17 responden $(32,70 \%)$ dan tinggi berjumlah 21 responden (40,38\%). Hal ini membuktikan bahwa pengetahuan ibu hamil tentang proses persalinan di wilayah Sukoharjo adalah tinggi. Pengetahuan adalah hasil "tahu", dan ini terjadi setelah orang melakukan pengindraan terhadap suatu objek tertentu. Pengindraan terjadi melalui panca indera manusia, yakni indera penglihatan, pendengaran, penciuman, rasa dan raba. Sebagian besar pengetahuan diperoleh melalui mata dan telinga. (Fitriani, 2011) Pengetahuan atau kognitif merupakan domain yang sangat penting untuk terbentuknya tindakan seseorang (overt behavior). Karena dari 
pengalaman dan penelitian
ternyata perilaku yang
didasarkan oleh pengetahuan
akan lebih langgeng daripada
perilaku yang tidak didasari oleh
pengetahuan. (Notoatmojo, 2011)
Menurut Wawan dan Dewi
(2011), faktor-faktor yang
mempengaruhi
pengetahuan adalah:

a. Umur

Menurut Huclok (1998), sebagaimana dikutip oleh Wawan dan Dewi (2011) semakin cukup umur, tingkat kematangan dan kekuatan seseorang akan lebih matang dalam berfikir. Dari segi kepercayaan masyarakat seseorang yang lebih dewasa dipercaya dari orang yang belum tinggi kedewasaannya. Hal ini akan sebagai dari pengalaman dan kematangan jiwa. Dalam penelitian ini salah satu faktor yang mempengaruhi tingkat pengetahuan ibu hamil adalah umur responden minimal 20 tahun mengalami kehamilan sebanyak 23 responden $(44,23 \%)$. Usia seseorang sangat berpengaruh terhadap kematangan berfikir sehingga lebih cepat menerima dan menangkap serta menganalisa sebuah informasi yang diperlukan dalam hal ini adalah tentang proses persalinan yang akan dialami atau merupakan pengalaman baru bagi yang sedang mengalami kehamilan pertama sedangkan yang sudah pernah mengalami proses persalinan bisa mempersiapkan diri menjadi lebih baik selama menjalani proses persalinan.

b. Sosial budaya

Sistem sosial budaya yang ada pada masyarakat dapat mempengaruhi dari sikap dalam menerima informasi. Data dari hasil penelitian ini responden yang telah mengalami kehamilan lebih dari satu kali sebanyak 27 responden $(51,92 \%)$.

2. Tingkat Kecemasan dalam Menghadapi Proses Persalinan Dari hasil tabel 4. dapat dicermati bahwa prosentase pada tingkat kecemasan menghadapi proses persalinan dengan kategori tidak cemas berjumlah 11 responden $(21,15 \%)$, kecemasan ringan berjumlah 10 responden $(19,23 \%)$, kecemasan sedang berjumlah 17 responden $(32,70$ $\%$ dan kecemasan berat berjumlah 14 responden (26,92\%). Hal ini membuktikan bahwa tingkat kecemasan ibu hamil adalah sedang.

Kecemasan adalah suatu perasaan tidak santai yang samar-samar karena ketidaknyamanan atau rasa takut yang disertai suatu respon (sumber sering kali tidak spesifik atau tidak diketahui oleh individu) suatu perasaan takut akan terjadi sesuatu yang disebabkan oleh antisipasi bahaya. Hal ini merupakan sinyal yang menyadarkan bahwa peringatan tentang bahaya yang akan datang dan memperkuat individu mengambil tindakan menghadapi ancaman. (Fitria, Sriati, dan Hernawaty, 2013)

Menurut Videbeck (2008) sebagaimana dikutip oleh Prabowo (2014), kecemasan adalah perasaan takut yang tidak jelas dan tidak didukung oleh situasi.

Ansietas menggambarkan rasa kecemasan, khawatir, gelisah dan tidak tentram yang disertai dengan gejala fisik. Ansietas merupakan bagian dari respon emosional terhadap penilaian individu yang subjektif yang keadaannya dipengaruhi alam 
bawah sadar. Selama periode kehamilan hampir sebagian besar ibu hamil sering mengalami kecemasan, yang membedakannya adalah tingkat kecemasannya. Setiap ibu hamil memiliki tingkat cemas yang berbeda-beda dan sangat tergantung pada sejauh mana ibu hamil itu mempersepsikan kehamilannya. Penyebab dari kecemasan adalah teori psikoanalitik, teori interpersonal, teori perilaku, teori eksistensi, kajian keluarga dan kajian biologis. (Murwani, 2008) Banyak ibu hamil merasa khawatir saat menghadapi kehamilan, terutama terhadap kesehatan bayi dan terhadap persalinan. Kekhawatiran tersebut sebenarnya normal dan tidak menandakan bahwa sesuatu yang buruk akan terjadi. lbu yang mengalami perasaan cemas membutuhkan dukungan emosi seperti seseorang untuk mendengarkan kekhawatiran dan memotivasinya untuk merasakan ada harapan. Dalam penelitian ini terdapat ibu hamil sebanyak 17 responden (32,70 \%) yang mengalami kecemasan sedang. Bila dikaitkan dengan beberapa teori di atas ada kemungkinan kecemasan yang sedang dialami oleh ibu hamil terutama trimester II dan III dalam menghadapi proses persalinan adalah kajian biologis dan psikoanalitik. Kecemasan yang dialami ibu hamil ada kemungkinan dikarenakan sebagian ibu hamil yaitu terdapat 25 ibu hamil $(48,08 \%)$ belum pernah mengalami persalinan yang artinya kehamilan saat ini adalah kehamilan yang pertama sehingga bisa memicu munculnya rasa cemas dalam menghadapi proses persalinan.

3. Hubungan Pengetahuan tentang Proses Persalinan dengan
Tingkat Kecemasan dalam Menghadapi Persalinan

Dari hasil penelitian Hubungan Pengetahuan tentang Proses Persalinan dengan Tingkat Kecemasan Menghadapi Persalinan diperoleh hasil Pearson Corelation program SPSS versi 18.0 dengan $\alpha=5 \%$ (0.05) diperoleh $\mathrm{p}<0,001$ sehingga nilai $p<0.05$, dengan hasil korelasi sangat tinggi $-0,928$ yang berarti $\mathrm{H}_{0}$ ditolak dan $\mathrm{H}_{a}$ diterima, sehingga ada korelasi negatif antara pengetahuan dengan tingkat kecemasan dalam menghadapi proses persalinan pada ibu hamil di wilayah Sukoharjo. Umumnya seorang wanita yang akan melahirkan akan mengalami rasa sakit atau rasa nyeri, sehingga persalinan dipersepsikan sebagai proses yang menakutkan dan menimbulkan rasa sakit yang luar biasa. Jika wanita yang akan melahirkan tidak dapat menahan rasa nyeri dan dibiarkan, hal yang dicemaskan adalah konsentrasi calon ibu menghadapi atau selama proses persalinan terganggu. Kecemasan dapat berkurang ketika ibu hamil telah mendapat informasi atau mengetahui apa yang akan terjadi pada dirinya dan pemeriksaan kehamilan (ANC) secara rutin, dukungan keluarga serta informasi dari bidan dan buku tentang persalinan, hal ini cenderung akan mengurangi rasa cemas yang dialaminya (Klein, Miller, dan Thomson, 2012)

Dari hasil penelitian ini diperoleh data pengetahuan ibu hamil tentang proses persalinan adalah tinggi $(40,38 \%)$ sedangkan tingkat kecemasan sedang $(32,70 \%)$, hal ini sesuai dengan teori di atas bahwa ketika ibu hamil mendapatkan informasi tentang ANC yang bisa diartikan 
ibu hamil memiliki pengetahuan tentang kehamilan dan proses persalinan setelah mendapatkan informasi sehingga rasa cemas yang terjadi selama proses kehamilan akan berangsurangsur menurun. Oleh karena itu dapat disimpulkan bahwa semakin tinggi pengetahuan ibu hamil tentang proses persalinan maka tingkat kecemasan ibu hamil akan semakin turun, hal ini sesuai dengan hasil korelasi yang sangat tinggi yaitu $-0,928$ yang artinya ada korelasi negatif antara pengetahuan dengan tingkat kecemasan dalam menghadapi proses persalinan pada ibu hamil di wilayah Sukoharjo.

Berdasarkan penelusuran pustaka yang penulis lakukan, ada beberapa penelitian terdahulu yang relevan dengan penelitian ini, diantaranya adalah Sekardani (2009) Penelitian berjudul hubungan antara pengetahuan ibu hamil tentang proses persalinan dengan tingkat kecemasan menghadapi persalinan di wilayah puskemas kerambitan tabanan bali. Sampel yang digunakan dalam penelitian ini berjumlah 38 orang dengan teknik pengambilan sampel kuota sampling. Analisis pengolahan data menggunakan uji statistik dengan rumus Kendal tau. Hasil penelitian menunjukkan tidak ada hubungan antara pengetahuan ibu hamil tentang proses persalinan dengan tingkat kecemasan menghadapi persalinan, dengan hasil uji statistik : correlation coefficient sebesar 0,327.

Sedangkan penelitian yang dilakukan oleh Suyanti dan Adawiyah (2009) Penelitian berjudul Hubungan tingkat pengetahuan ibu hamil tentang proses persalinan dengan tingkat kecemasan menghadapi persalinan di desa Sambirejo Jogoroto. Sampel yang digunakan dalam penelitian ini yaitu sebanyak 48 responden ibu hamil. Data yang terkumpul diuji analisis menggunakan uji korelasi Spearman Rank. Hasil penelitian menunjukkan 60,4\% ibu hamil mempunyai tingkat pengetahuan yang baik tentang persalinan dan $60,4 \%$ ibu hamil memiliki tingkat kecemasan ringan. Hasil uji statistik menunjukkan signifikansi $0,013<0,05$ sehingga dapat disimpulkan bahwa ada hubungan antara pengetahuan ibu hamil dengan tingkat kecemasan dalam menghadapi persalinan.

\section{KESIMPULAN}

1. Responden dengan pengetahuan terbanyak adalah tinggi terdapat 21 responden (40,38\%), pengetahuan sedang terdapat 17 responden (32,70\%) dan pengetahuan rendah terdapat 14 responden (26,92\%).

2. Responden dengan tingkat kecemasan terbanyak adalah kategori sedang terdapat 17 responden $(32,70 \%)$, tingkat kecemasan berat terdapat 14 responden (26,92\%), tingkat kecemasan ringan terdapat 10 responden $(19,23 \%)$ dan yang tidak mengalami kecemasan terdapat 11 responden $(21,15 \%)$.

3. Dari hasil uji Pearson Corelation program SPSS versi 18.0 dengan $\alpha=5 \%$ (0.05) diperoleh $p<0,001$ sehingga nilai $p<0.05$, dengan hasil korelasi $-0,928$ yang berarti $\mathrm{H}_{\mathrm{o}}$ ditolak dan $\mathrm{H}_{\mathrm{a}}$ diterima, sehingga ada korelasi negatif antara pengetahuan dengan tingkat kecemasan dalam menghadapi proses persalinan pada ibu hamil di wilayah Sukoharjo. 


\section{SARAN}

Bagi ibu hamil disarankan untuk memperoleh informasi yang lebih banyak tentang ANC dan proses persalinan dikarenakan semakin tinggi pengetahuan akan menurunkan tingkat kecemasan ibu hamil dalam menghadapi proses persalinan. Sedangkan bagi institusi pendidikan kesehatan disarankan untuk memanfaatkan hasil penelitian ini untuk pengembangan proses pembelajaran khususnya dalam keperawatan maternitas.

\section{DAFTAR PUSTAKA}

Departemen Kesehatan Republik Indonesia. Jadilah Kartini Indonesia yang tidak Mati Muda (Pencanangan Kampanye Peduli Kesehatan Ibu 2014). 2014. URL: http://www.depkes.go.id/ article. Diakses 23 November 2015.

Fitria, N., Sriati, A. dan Hernawaty, T. 2013. Laporan Pendahuluan tentang Masalah Psikososial. Salemba Medika, Jakarta.

Fitriani, S. 2011. Promosi Kesehatan. Graha IImu, Yogjakarta.

Hutahaean, S. 2013. Perawatan Antenatal. Salemba Medika, Jakarta.

Klein, S., Miller, S., dan Thomson, F. 2012. Buku Bidan : Asuhan pada Kehamilan, Kelahiran, \& Kesehatan Wanita. Alih Bahasa Dwi Widiarti, Devi Yulianti, Fruriolina Ariani. EGC, Jakarta.

Murwani, A. 2008. Pengantar Konsep Dasar Keperawatan. Citramaya, Yogjakarta.
Notoatmodjo, S. 2011. Promosi Kesehatan dan IImu Perilaku. Rineka Cipta, Jakarta.

Prabowo, E. 2014. Konsep dan Aplikasi Asuhan Keperawatan Jiwa. Nuha Medika, Yogyakarta.

Sekardani, N. L. P. 2009. Hubungan Antara Pengetahuan Ibu Hamil Tentang Proses Persalinan dengan Tingkat Kecemasan Menghadapi Persalinan. URL: file:///l:/abstrakriset/hubunganantara-pengetahuan-ibuhamiltentang-proses-persalinandengan-tingkat-kecemasan menghadapi-persalinan. Diakses 23 November 2015.

Suyanti, A. N. dan Adawiyah, S. R. 2009. Hubungan Antara Pengetahuan Ibu Hamil Tentang Proses Persalinan dengan Tingkat Kecemasan Menghadapi Persalinan. URL: file:////:/abstrakriset/hubunganantara-pengetahuan-ibuhamiltentang-proses-persalinandengan-tingkat-kecemasan menghadapi-persalinan. Diakses 23 November 2015

Walsh, L. V. 2008. Buku Ajar Kebidanan Komunitas. Alih bahasa Wilda Eka Handayani, Sifing Lestari dan Nia Damiati. EGC, Jakarta.

Wawan, A. dan Dewi, M. 2011. Teori dan Pengukuran Pengetahuan Sikap dan Perilaku Manusia. Nuha Medika, Yogjakarta.

${ }^{1}$ Dosen Akper Panti Kosala Surakarta

${ }^{2}$ Mahasiswa Akper Panti Kosala Surakarta 
••KOsคเn״ JIK. Vol. 4 No. 2 September 2016 